\title{
PREVALENCE AND PREDICTORS OF IMPAIRED \\ GLUCOSE TOLERANCE AND DIABETES MELLITUS TYPE 2 IN PATIENTS WITH POLYCYSTIC OVARY SYNDROME
}

\author{
Brankica Krstevska ${ }^{1}$, Sasha Jovanovska Mishevska ${ }^{2}$, \\ Valentina Velkoska Nakova $^{3}$, Vladimir Serafimoski ${ }^{4}$ \\ ${ }^{1}$ Internal Medicine Centre "Srce", Skopje, N Macedonia \\ ${ }^{2}$ University Clinic of Endocrinology, Diabetes and Metabolic Disorders, Skopje, N Macedonia \\ ${ }^{3}$ Clinical Hospital, Shtip, N Macedonia \\ ${ }^{4}$ Macedonian Academy of Science, Skopje, N Macedonia
}

Corresponding author: Brankica Krstevska, Internal Medicine Centre "Srce", Skopje, North Macedonia, e-mail: branakrstevska@yahoo.com

\section{ABSTRACT}

Aim: To estimate the prevalence of impaired glucose tolerance (IGT) and diabetes mellitus type 2 (DMT2), as well as the predictors for glucose abnormalities in women with polycystic ovary syndrome (PCOS).

Material and methods: A cross-sectional study with 80 consecutive patients with newly diagnosed PCOS who underwent the standard $75 \mathrm{~g}$ oral glucose tolerance test (OGTT) and the measurement of sex steroid hormone and lipid profile.

Results: According to the results from the OGTT, 63\% had a normal test (NT), 23\% had IGT, and 9\% had DMT2. The NT group was younger with lower BMI than IGT and DMT2 groups $(25.1 \pm 7.3,31.5 \pm$ $6.5,37.4 \pm 4.0$ years, and $29.1 \pm 8.3 \mathrm{~kg} / \mathrm{m} 2,31.7 \pm 4.6 \mathrm{~kg} / \mathrm{m} 2$, and $34.5 \pm 5.6 \mathrm{~kg} / \mathrm{m} 2$, respectively). The testosterone levels were highest in the group with a normal test $(2.7 \pm 0.8 \mathrm{nmol} / \mathrm{l})$ and lowest in the DMT2 group $(1.9 \pm 0.8 \mathrm{nmol} / \mathrm{L})$, with statistical significance. The sex hormone bounding globulin (SHBG) levels were low in all three groups, with statistically significant differences between NG and IGT, and the NT and DMT2 groups. The multivariate linear regression model identified age, BMI, SHBG and testosterone as major independent predictors for abnormal glucose metabolism.

Conclusion: It seems that the prevalence of IGT and DMT2 among PCOS women in our country is not as high as in Western countries. Age, BMI, and SHBG increase the risk for the development of IGT and DMT2. Thus, close monitoring of older, obese women with low SHBG is needed because of the higher risk for the development of IGT and DMT2 in such patients.

Keywords: polycystic ovary syndrome, OGTT, IGT, DMT2, testosterone

\section{INTRODUCTION}

PCOS is the most common endocrine disease affecting from $3 \%$ to $16 \%$ of women of reproductive age. PCOS is a metabolic-reproductive disorder with a very complex and not fully understood pathophysiology. Of note, accumulating evidence in literature indicates that hyperinsulinemia is secondary to insulin resistance (IR) and plays an important role in the pathogenesis of the syndrome [1]. Tissues normally responsive to insulin for glucose uptake, such as the heart and skeletal muscle, protect themselves from nutrient-induced toxicity 
by becoming insulin resistant [2]. Insulin resistance is the central mechanism linking together all parameters of the metabolic syndrome, such as: impaired glucose tolerance (IGT), type 2 diabetes mellitus (DMT2), hyperlipidemia and cardiovascular disease over-time [3-5]. Adolescent girls with PCOS have been shown to have early-onset insulin hypersecretion in association with insulin resistance [2], and approaches for reversal of severe hyperinsulinemia early in its course, prevented them from developing health problems later in life, such as diabetes, cardiovascular disease and infertility [6].

In spite of insulin resistance, some women with PCOS demonstrated beta cell dysfunction. Thus, both IR and beta cell dysfunction contribute to the development of DMT2 [7, 8]. Defects in insulin action and inadequate insulin response to glucose load have been found predominantly in obese $[1,7]$ and less in lean women with PCOS [9]. The risk for DMT2 in women with PCOS is estimated to be 5 to 10 -fold higher than factors including age and weight, when compared with the normal control population.

In 1921 Archer and Thiers first reported a relationship between hyperandrogenism and insulin metabolism in their description of "diabetes des femmes a barbe" [10]. In 1980, Burghen and colleagues described a strong correlation between plasma insulin concentrations and testosterone and androstenedione in obese women with PCOS [11]. It became clear that PCOS also includes major metabolic morbidities. Hyperinsulinemia and peripheral insulin resistance are, however, the central feature of metabolic disorders, which is recognized to be typical of PCOS. Epidemiological studies and meta-analysis showed that the onset of IGT and DMT2 appears at an earlier age in patients with PCOS [12-14]. The risk for dysglycemia is the highest among PCOS patients with both anovulation and hyperandrogenism, amplified by obesity, or the classic NIH phenotype [15]. Recently, it has become clear that not only age but also obesity, family history of DMT2 and hyperandrogenaemia may contribute to the increasing risk of diabetes in PCOS.

PCOS is a major risk factor for IGT and DMT2, with different prevalence among countries worldwide. Other factors may contribute to this heterogeneous prevalence, such as ethnicity, age, BMI, insulin resistance, dyslipidemia, and reproductive hormones. The aim of this study is to estimate the prevalence of IGT and
DMT2 among Macedonian women diagnosed with PCOS and to identify the parameters (age, BMI, testosterone, sex hormone bounding globulin, lipids) as predictors for abnormal glucose tolerance.

\section{MATERIALS AND METHODS}

At the University Clinic of Endocrinology, Diabetes and Metabolic Disorders, Skopje, we conducted a cross-sectional study, including patients with PCOS. Applying the Rotterdam diagnostic criteria for PCOS [16], 80 women with PCOS were included and they were screened for glucose intolerance using the oral glucose tolerance test (OGTT) according to the ADA criteria [17].

PCOS was diagnosed when 2 out of the following 3 criteria were present: oligoanovulation and/or anovulation, clinical and/or biochemical signs of hyperandrogenism, and polycystic ovaries on ultrasound examination. Oligoanovulation was defined as the presence of oligomenorrhea (menstrual cycles of $>35$ days) or amenorrhea (lack of a menstrual period for 6 months or more). Clinical signs of hyperandrogenism were the presence of hirsutism, acne/seborrhea or alopecia. Biochemical hyperandrogenism was established based on elevated total or bioavailable testosterone levels, and DHEAs. Hirsutism was defined as an Ferriman-Gallwey score that was $>8$. Ovaries were classified as polycystic if 10 or more follicles measuring $2-8 \mathrm{~mm}$ in diameter were present in each ovary, and/or there was an increase in the ovarian volume $>10 \mathrm{ml}$. Transvaginal ovarian ultrasound scanning was performed between days 5 and 10 from the beginning of the last menstrual cycle using a $7.5-\mathrm{MHz}$ vaginal probe transducer (General Electric LOGIQ 400MD, Milwaukee, WI, USA). Both ovaries were measured in the sagittal, transverse, and coronal planes.

All patients were in their reproductive period, free of chronic disease, including diabetes and hypertension. None of the women with PCOS had taken any oral contraceptive, other forms of hormonal contraception or fertility treatments.

All of the patients underwent 75-g OGTT, following the ADA criteria [17]. 75-g of hydrous glucose load was briefly administered after a 12 to 14 hour period of fasting and 2 hours post - 
load samples for glucose were obtained from an antecubital vein. The samples were collected in tubes containing fluoride and kept at $4^{\circ} \mathrm{C}$ until centrifugation up to 2 hours later. Plasma measurements were performed with glucose oxidase methods.

The patients were divided into three groups according to the results from the OGTT: patients with a normal test (NT), impaired glucose tolerance (IGT) and patients with type 2 diabetes mellitus (DMT2). IGT and DMT2 were diagnosed according to the recommendations of the American Diabetes Association [17].

In all patients the following parameters were analyzed: patients' age, body mass index (BMI), days of the menstrual cycle, Ferriman-Gallwey score, waist/hip ratio, FSH, LH, estradiol (E2), total and free testosterone, DEHAs, 17-OHP, PRL, SHBG, fasting plasma glucose (FPG), 2 hour OGTT glucose values, and lipid parameters.

The BMI of women was calculated by dividing their weight by their squared height in meters $(\mathrm{kg} / \mathrm{m} 2)$. The days of the menstrual cycle were self-reported by the patients. Hirsutism scoring scale of Ferriman and Gallwey was used. Waist/hip ratio was calculated. A morning blood sample was obtained after an overnight fast from all subjects for measuring hormones and lipoprotein parameters.
All hormones were measured in our laboratory using commercial kits. These included ELISA (DRG Diagnostics, DRG Instruments GmbH, Marburg, Germany) for FSH, LH, E2, 17-OHP, PRL, total and free testosterone. Chemiluminescence assays were used for DHEAs and SHBG. The blood samples for lipoproteins were analyzed using Cobas Integra 700, according to standard methods. Total cholesterol and triglycerides were determined by full enzymatic methods (THCHOD-POD-PAP and triglycerides-GPO; Cobas Integra 700, Hoffmann-La Roche, Basel, Switzerland). HDL-C was measured using the polyanion precipitation method, while LDL-C was calculated using the Friedewald formula.

The criteria for diagnosing type $2 \mathrm{DM}$ and IGT were, as recommended by ADA [17], as follows: fasting plasma glucose, normal $<5.6$ $\mathrm{mmol} / \mathrm{l}$; IFG, 5.6- $6.9 \mathrm{mmol} / \mathrm{l}$; DMT2, $7.0 \mathrm{mmol} / \mathrm{l}$. Two hour values: normal, $7.7 \mathrm{mmol} / \mathrm{l}$; IGT, 7.8 -11.0 mmol/l; DMT2, $11.1 \mathrm{mmol} / \mathrm{l}$.

Normal laboratory values of other testing used were: total testosterone, normal, $<2.1 \mathrm{nmo-}$ 1/l; SHBG, 52 - $150 \mathrm{nmol} / 1$; cholesterol 3.4 -5.2 $\mathrm{mmol} / \mathrm{l}$; triglycerides, $0.45-1.7 \mathrm{mmol} / 1$.

All patients gave informed consent to participate in the study after receiving explanations regarding the research protocols. The study was done according to the Helsinki Declaration.

Table 1. Comparison of the analyzed parameters between patients with normal OGTT, IGT and DMT2

\begin{tabular}{|c|c|c|c|c|}
\hline & $\begin{array}{l}\text { NT } \\
n=58 \\
(1)\end{array}$ & $\begin{array}{l}\text { IGT } \\
n=16 \\
(2)\end{array}$ & $\begin{array}{l}\text { DMT2 } \\
n=6 \\
(3)\end{array}$ & significance \\
\hline Age (years) & $25.1 \pm 7.3$ & $31.5 \pm 6.5$ & $37.4 \pm 4 ., 0$ & $1: 2 ; 1: 3(p<0.05)$ \\
\hline F-G scor & $17.2 \pm 7.4$ & $18.5 \pm 7.8$ & $11.3 \pm 3.0$ & $\mathrm{HC}$ \\
\hline $\begin{array}{l}\text { Days of the menstrual } \\
\text { cycle }\end{array}$ & $75.7 \pm 52$ & $76.1 \pm 50.9$ & $54 \pm 22.2$ & $\mathrm{HC}$ \\
\hline BMI $\left(\mathrm{kg} / \mathrm{m}^{2}\right)$ & $29.1 \pm 8.3$ & $31.7 \pm 4.6$ & $34.5 \pm 5.6$ & $\mathrm{HC}$ \\
\hline waist/hip ratio $(\mathrm{cm})$ & $0.76 \pm 0.06$ & $0.78 \pm 0.08$ & $0.77 \pm 0.02$ & $\mathrm{HC}$ \\
\hline FSH (IU/L) & $5.4 \pm 1.7$ & $4.7 \pm 1.4$ & $7.5 \pm 2.3$ & $2: 3(\mathrm{p}<0.05)$ \\
\hline LH (IU/L) & $9.8 \pm 4.9$ & $8.6 \pm 6.5$ & $11.2 \pm 4.4$ & $\mathrm{HC}$ \\
\hline E2 (pmol/L) & $55.4 \pm 39$ & $63.4 \pm 52.5$ & $50.1 \pm 15.0$ & $\mathrm{HC}$ \\
\hline Testosteron (ng/dL) & $2.7 \pm 0.8$ & $2.4 \pm 0.9$ & $1.9 \pm 0.8$ & $1: 3(\mathrm{p}<0.05)$ \\
\hline F Testosteron & $9.1 \pm 8.1$ & $10.3 \pm 7.1$ & $8.9 \pm 4.7$ & $\mathrm{HC}$ \\
\hline DEHAs ( $\mu \mathrm{mol} / \mathrm{L})$ & $9.0 \pm 3.6$ & $6.7 \pm 3.5$ & $3.5 \pm 2.7$ & $1: 3(p<0.05)$ \\
\hline 17-OHP (nmol/L) & $5.1 \pm 2.7$ & $8.1 \pm 5.2$ & $6.3 \pm 2.8$ & $\mathrm{HC}$ \\
\hline PRL (pmol/L) & $18.7 \pm 11.0$ & $18.8 \pm 8.5$ & $17.6 \pm 7.6$ & $\mathrm{HC}$ \\
\hline SHBG (nmol/L) & $37.8 \pm 15.7$ & $27.1 \pm 11.1$ & $22.3 \pm 7.5$ & $1: 2 ; 1: 3(p<0.05)$ \\
\hline OGTT-0' (mmol/L) & $4.7 \pm 0.5$ & $5.6 \pm 0.7$ & $6.8 \pm 1.6$ & $1: 2 ; 1: 3 ; 2: 3(p<0.05)$ \\
\hline OGTT-120' $(\mathrm{mmol} / \mathrm{L})$ & $5.8 \pm 1.0$ & $8.7 \pm 0.9$ & $11.8 \pm 0.2$ & $1: 2 ; 1: 3 ; 2: 3(p<0.05)$ \\
\hline Total lipids (mmol/L) & $8.2 \pm 1.9$ & $8.6 \pm 0.9$ & $8.4 \pm 0.8$ & $\mathrm{HC}$ \\
\hline Triglicerides (mmol/L) & $1.31 \pm 0.6$ & $1.69 \pm 0.70$ & $2.33 \pm 0.58$ & $1: 3(p<0.05)$ \\
\hline T.Cholesterol (mmol/L) & $4.8 \pm 1.0$ & $4.82 \pm 0.78$ & $4.83 \pm 0.40$ & $\mathrm{HC}$ \\
\hline HDL-C (mmol/L) & $1.1 \pm 0.2$ & $1.13 \pm 0.36$ & $1.0 \pm 0.14$ & $\mathrm{HC}$ \\
\hline LDL-C (mmol/L) & $3.2 \pm 1.1$ & $3.20 \pm 1.05$ & $2.75 \pm 0.91$ & $\mathrm{HC}$ \\
\hline
\end{tabular}

*Data are presented as mean \pm SD. Student T-tests were used for analyzing the differences between the groups.

**F-G scor: Ferriman and Gallwey score system; BMI: body mass index; FSH: foliculostimulating hormone; LH: luteinization hormone; E2: estradiol; F testosterone: free testosterone; DHEAs: dehydroepiandrosterone sulfate ; 17-OHP: 17-hydroxyprogesterone; PRL: prolactin; SHBG: sex hormone-binding globulin; OGTT-0': fasting glucose; OGTT-120': 2-hr glucose after 75 g oral glucose load; T. Cholesterol: total cholesterol; HDL-C: high density cholesterol; LDL-C: low density cholesterol. 
The Statistical Package Statistics, version 7.0 was used. Baseline characteristics were expressed as a mean \pm S.D.Shapiro-Wilk test, showing that all variables have normal distribution. Differences between groups were detected by unpaired Student's t test for continuous variables. The correlation between the tested parameters was determined using Pearson's $\mathrm{R}$ for correlation. A GLM multivariate analysis was used for the evaluation of the independent effect of the analyzed variables on fasting, and 2 hour glucose values from OGTT. The value of $p<0.05$ was taken as statistically significant.

\section{RESULTS}

The demographic, anthropometric, and biochemical (hormonal and lipid parameters) characteristics of the 80 women with PCOS are presented in Table 1.

The prevalence of alterations in glucose tolerance was as follows: IGT 16/80 (23\%) and DMT2 6/80 (9\%).

The women who had normal glucose tolerance were significantly younger than the women with PCOS and altered glucose tolerance. BMI was lower in women with normal glucose tolerance compared to women with altered glucose tolerance, but the differences were not statistically significant. With regard to the hormonal profile, the only difference found between the women with normal glucose tolerance and the IGT group was the statistically significantly lower level of SHBG. Interestingly, there were significantly lower levels of total testosterone and DHEAs in women with DMT2, than in women with normal glucose tolerance. Also, SHBG was significantly lower in the DMT2 group than in women with normal glucose tolerance (Table 1).

The glycemic values from OGTT of women with IGT and DMT2 were significantly higher compared to women with normal glucose tolerance (Table 1, Graph 1). The results from the lipid profile showed significantly higher triglyceride levels in women with DMT2 than in women with normal glucose tolerance (Table 1).

The results from the correlation revealed the following statistically significant correlation: a positive correlation between age and fasting glycaemia, and age with 2 hours post-load glucose from OGTT, a negative correlation between the SHBG and both glycemic values from OGTT, and a positive correlation between the 2 hours postload glucose and triglycerides, and BMI.

Multivariate linear regression was used to determine the independent impact of the analyzed parameters on the OGTT-0' and OGTT-120' plasma glucose values. BMI, total testosterone, DHEAs, SHBG, and total cholesterol were shown to have an independent effect on the fasting glycaemia in PCOS women (Table 2). Age, BMI, total testosterone, DHEAs, SHBG, total lipids, total cholesterol, and HDL-C have an independent effect on 2 hour post-load glucose from OGTT in PCOS women (Table 3 ).

We compared our results with those from other countries, trying to explain the differences of IGT/DMT2 prevalence in our cohort to others, and we found mostly higher results, but also some lower prevalence which can partly be explained with the magnitude of BMI (Table 4) [12, 18-23].

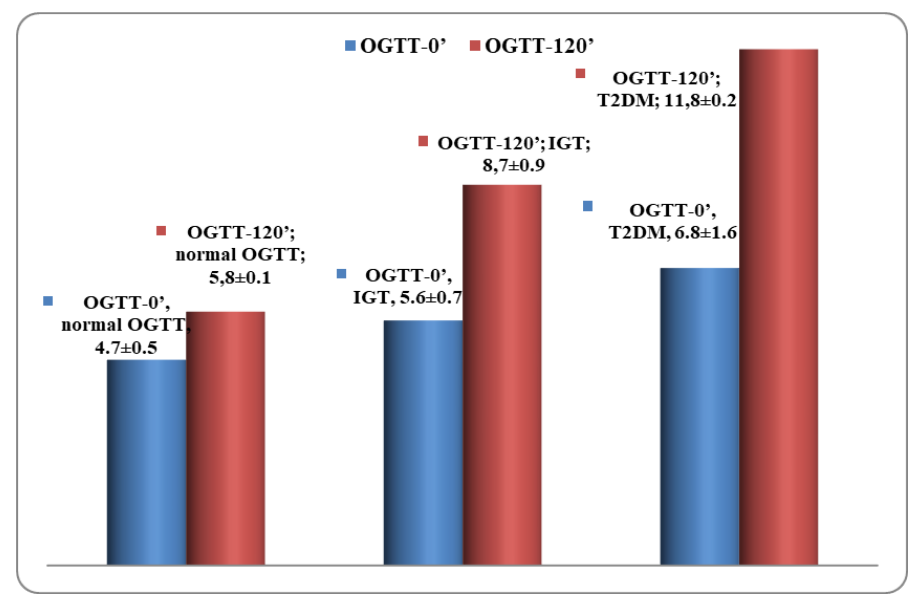

Graph 1. Comparison of glycemic values (mmol/l) from OGTT between the women with normal glucose tolerance, IGT, and DMT2 
Table 2. Independent effect of analyzed parameters on OGTT-0'

\begin{tabular}{|l|c|c|c|}
\hline & df & F & p-value \\
\hline Model & 1 & 20.00037 & 0.000008 \\
\hline age & 1 & 3.00378 & 0.083070 \\
\hline BMI & $\mathbf{1}$ & $\mathbf{6 . 8 8 4 2 9}$ & $\mathbf{0 . 0 0 8 6 9 6}$ \\
\hline Testosteron & $\mathbf{1}$ & $\mathbf{2 9 . 7 6 0 3 6}$ & $\mathbf{0 . 0 0 0 0 0 0}$ \\
\hline DEHAs & $\mathbf{1}$ & $\mathbf{5 . 5 0 1 9 4}$ & $\mathbf{0 . 0 1 8 9 9 5}$ \\
\hline SHBG & $\mathbf{1}$ & $\mathbf{1 4 . 9 4 3 8 4}$ & $\mathbf{0 . 0 0 0 1 1 1}$ \\
\hline Total lipids & 1 & 0.03744 & 0.846578 \\
\hline Triglycerides & 1 & 0.66487 & 0.414847 \\
\hline T. Ch & $\mathbf{1}$ & $\mathbf{1 5 . 9 1 7 1 1}$ & $\mathbf{0 . 0 0 0 0 6 6}$ \\
\hline HDL-C & 1 & 0.21245 & 0.644853 \\
\hline LDL-C & 1 & 0.23702 & 0.626369 \\
\hline
\end{tabular}

*DHEAs: dehydroepiandrosterone sulfate ; SHBG: sex hormone-binding globulin; OGTT-0': fasting glucose; T. Cholesterol: total cholesterol; HDL-C: high density cholesterol; LDL-C: low density cholesterol.

Table 3. Independent effect of analyzed parameters on OGTT-120'

\begin{tabular}{|l|c|c|c|}
\hline & df & F & p-value \\
\hline Model & 1 & 49.78806 & 0.000000 \\
\hline age & $\mathbf{1}$ & $\mathbf{5 . 8 7 8 1 2}$ & $\mathbf{0 . 0 1 5 3 3 0}$ \\
\hline BMI & $\mathbf{1}$ & $\mathbf{1 9 . 6 7 2 0 3}$ & $\mathbf{0 . 0 0 0 0 0 9}$ \\
\hline Testosteron & $\mathbf{1}$ & $\mathbf{1 4 . 6 2 1 3 6}$ & $\mathbf{0 . 0 0 0 1 3 1}$ \\
\hline DEHAs & $\mathbf{1}$ & $\mathbf{1 6 . 3 2 8 0 5}$ & $\mathbf{0 . 0 0 0 0 5 3}$ \\
\hline SHBG & $\mathbf{1}$ & $\mathbf{2 2 . 3 2 2 9 0}$ & $\mathbf{0 . 0 0 0 0 0 2}$ \\
\hline Total lipids & $\mathbf{1}$ & $\mathbf{4 . 1 6 3 0 4}$ & $\mathbf{0 . 0 4 1 3 1 5}$ \\
\hline Triglycerides & 1 & 1.99268 & 0.158061 \\
\hline T. Ch & $\mathbf{1}$ & $\mathbf{4 2 . 0 7 6 1 8}$ & $\mathbf{0 . 0 0 0 0 0 0}$ \\
\hline HDL-C & $\mathbf{1}$ & $\mathbf{5 . 3 5 1 6 8}$ & $\mathbf{0 . 0 2 0 7 0 2}$ \\
\hline LDL-C & 1 & 2.43199 & 0.118882 \\
\hline
\end{tabular}

*DHEAs: dehydroepiandrosterone sulfate ; SHBG: sex hormone-binding globulin; OGTT-0': fasting glucose; T. Cholesterol: total cholesterol; HDL-C: high density cholesterol; LDL-C: low density cholesterol.

Table 4. Comparison of prevalence of IGT and DMT2 in our study and the results from the other countries

\begin{tabular}{|c|c|c|c|c|c|c|}
\hline Author and year & Ethnicity & $\mathbf{N}$ & $\begin{array}{c}\text { Age (years) } \\
\text { mean } \pm \text { SD } \\
(\min -\max )\end{array}$ & $\begin{array}{c}\mathrm{BMI}\left(\mathrm{kg} / \mathbf{m}^{2}\right) \\
\operatorname{mean} \pm \mathrm{SD}\end{array}$ & $\begin{array}{l}\text { IGT } \\
(\%) \\
\end{array}$ & $\begin{array}{c}\text { T2DM } \\
(\%)\end{array}$ \\
\hline $\begin{array}{l}\text { Ehrmann et al. } \\
\text { (1999) [12] }\end{array}$ & $\begin{array}{c}52 \% \text { Caucasian } \\
36 \% \text { African } \\
\text { American USA } \\
8 \% \text { Asian, 4\% } \\
\text { Hispanic }\end{array}$ & 122 & $\begin{array}{c}25.5 \pm 0.7 \\
(14-40)\end{array}$ & $\begin{array}{c}\text { NGT } 33.4 \pm 1.1 \\
\text { IGT } 36.9 \pm 1.2 \\
\text { DMT2 } 41.0 \pm 2.4\end{array}$ & 35 & 10 \\
\hline \multirow{2}{*}{$\begin{array}{l}\text { Legro et al. (1999) } \\
{[18]}\end{array}$} & \multirow{2}{*}{$\begin{array}{l}57 \% \text { Caucasian } \\
\text { USA }\end{array}$} & 110 & \multirow{2}{*}{$\begin{array}{c}27 \pm 5 \\
28 \pm 6 \\
(14-44) \\
\end{array}$} & $29.9 \pm 8.1$ & 30 & 7.3 \\
\hline & & 144 & & $35.9 \pm 8.0$ & 31.9 & 7.6 \\
\hline $\begin{array}{l}\text { Weerakient et al. } \\
\text { (2001) [19] }\end{array}$ & Thai & 79 & $28.2 \pm 6.2$ & $27.2 \pm 5.9$ & 20.3 & 17.7 \\
\hline $\begin{array}{l}\text { Gambieneri et al. } \\
\text { (2004) }[20]\end{array}$ & Mediterranean & 121 & $\begin{array}{c}- \\
(14-37)\end{array}$ & $84.3 \%>25 \mathrm{~kg} / \mathrm{m} 2$ & 15.7 & 2.5 \\
\hline $\begin{array}{l}\text { Dabadghao et al. } \\
\text { (2007) [21] }\end{array}$ & $\begin{array}{l}\text { Caucasian } \\
\text { Australian }\end{array}$ & 372 & $\begin{array}{c}30.3 \pm 5.6 \\
(15-62)\end{array}$ & $35.1 \pm 8.0$ & 15.6 & 4 \\
\hline $\begin{array}{l}\text { Apridonidze et al. } \\
\text { (2005) [22] }\end{array}$ & $\begin{array}{c}92,4 \% \text { Caucasian } \\
\text { USA }\end{array}$ & $\begin{array}{l}46 \\
60\end{array}$ & $(20-40)$ & $\begin{array}{c}\mathrm{NMS}^{*} 33.7(31.67- \\
35.85)^{* *} \\
\mathrm{MS}^{*} 39.3(36.8- \\
41.57)^{* *}\end{array}$ & 11 & 8 \\
\hline $\begin{array}{l}\text { Carmina et al. } \\
(2006)[23]\end{array}$ & Italian & 282 & $24.9 \pm 0.1$ & $27.2 \pm 0.3$ & 12.4 & - \\
\hline Our study & Caucasian & 80 & $27.5 \pm 7.9$ & $30.3 \pm 7.4$ & 23 & 9 \\
\hline
\end{tabular}

*NMS- without metabolic syndrome, MS-with metabolic syndrome

** mean BMI (min-max values of BMI) 


\section{DISCUSSION}

Studies have shown that abnormal glucose tolerance is present in overweight and obese women with PCOS, compared to women without PCOS [18, 24]. One recent review [25] confirms the original findings of an increased prevalence of IGT and DMT2 among PCOS women in comparison to normal controls. This study revealed that $23 \%$ (16/80 patients) of women with PCOS had IGT while $9 \%$ (6/80 patients) had DMT2. The finding is in line with the prevalence of impaired glucose tolerance in Italian and European women with PCOS [23]. Different studies from the literature show that IGT was present in $35 \%$ of US women and 47\% in Asian obese women [19] and in low to moderate weight women from Europe, at first clinical examination [25]. The International Diabetes federation [26] identified PCOS women as a non-modifiable risk factor for DMT2.

Differences in the results may be due to different ages, BMI, ethnicity, the impact of environmental factors, particularly dietary habits, and number of enrolled patients. The prevalence of IGT/DMT2 in our study is lower than the prevalence found in women from the USA and Asia, and higher compared to Australian, Italian and Mediterranean women.

PCOS women show a tendency to develop IGT/DMT2 at an early age and the prevalence is higher when compared to the general population $[14,27]$. In our study, IGT was detected in the third decades and DMT2 in the fourth decades. Furthermore, we demonstrated a statistically significant positive correlation between age and FPG, and age with 2 hour post-load glycaemia from OGTT. It is notable that age was the contributing factor to have IGT in the third decade and DMT2 in the fourth decades, meaning that clinicians should keep this in mind. Age has an independent effect on 2 hour post-load glucose from OGTT.

Obesity is common among PCOS women [28]. There is a great variability of overweight $(25-30 \mathrm{~kg} / \mathrm{m} 2)$ and obese $(>30 \mathrm{~kg} / \mathrm{m} 2)$ in the PCOS women among different population. The proportion of PCOS women who are overweight is $10 \%$ in Italy and $37 \%$ in Kuwait. The studies from the USA and Australia reported the highest prevalence of obesity, from $61 \%$ to $76 \%$ in PCOS women [23]. Obesity has a crucial role in the de- velopment and maintaining of PCOS [29], and it significantly influences the severity of metabolic abnormalities. Obesity is also a major modifiable risk factor for DMT2 in women with PCOS [30]. In our study, we have found that women with IGT and diabetic PCOS women are significantly more obese in comparison to those with normal glucose tolerance $(31.7 \pm 4.6 \mathrm{~kg} / \mathrm{m} 2,34.5 \pm 5.6 \mathrm{~kg} / \mathrm{m} 2$, $29.1 \pm 8.3 \mathrm{~kg} / \mathrm{m} 2$, respectively). Obesity has a major impact on the development of PCOS, even more so in the creation of the phenotype of PCOS. Menstrual irregularity, hirsutism, and hyperandrogenemia are associated with morbid obesity in PCOS women. A recent review [14] showed that American and Asian obese women are presented predominantly with metabolic syndrome or the metabolic PCOS phenotype. European women are prone to hirsutism, acne, androgenic alopecia or the hyperandrogenic phenotype. Otherwise lean women with PCOS are rarely diagnosed with DMT2 and only a few percent of normal-weight women have prediabetes. Therefore, regular screening is recommended, particularly in overweight or obese patients and in those with a family history of DMT2, in order to identify impaired glucose metabolism early on [31]. The lower prevalence of IGT/DM2 in our patients with PCOS is partly due to the lower BMI in our study, a finding similar to other Mediterranean countries.

According to the recent guidelines of the American Association of Clinical Endocrinologists, the American College of Endocrinology, and the Androgen Excess and PCOS Society, OGTT should be performed at the moment of diagnosis of PCOS and every 1 to 2 years in patients with PCOS based on a family history of DMT2 and $\mathrm{BMI}>30 \mathrm{~kg} / \mathrm{m} 2$, whereas this test should be performed every year in patients with PCOS and IGT [32].

PCOS is the condition that most often causes elevated testosterone concentrations, and PCOS consensus criteria define hyperandrogenemia on the basis of serum testosterone. Hyperandrogenemia is strongly associated with a diabetes risk in PCOS women. An important pathogenic element for DMT2 is insulin resistance. It is well known that hyperinsulinemia stimulates ovarian theca cells, thereby increasing androgen production and synergistically via LH hypersecretion. Therefore, another contributing factor to abnormal glucose tolerance is the interrelation between insulin resistance and hyperandrogenemia [33]. Hyperandrogenemia has been reported to increase insulin 
resistance through the inflammation pathway, which could contribute to hyperglycemia. The correlation between high testosterone levels and insulin concentrations during OGTT may be interpreted as a marker of insulin resistance without direct contribution to the development of diabetes, possibly through the inflammation pathway. This finding was documented by Ehrmann et al. in 1999 for the first time [12] and was confirmed by Shorakae et al. [34]. In our study, multiple linear regression analysis showed that total testosterone has an independent impact on fasting glycaemia and on 2 hour post-load glucose from OGTT in PCOS women. This data from our PCOS cohort shows that other factors associated with abnormal glucose tolerance included testosterone, as well as elevated age and obesity. It seems that the incidence of dysglucaemia, according to an oral glucose tolerance test, increased with severity of the androgen phenotype. However, co-measurement of both androstenedione and testosterone can help to discover the PCOS cohort which is highest for metabolic risk [35].

Insulin resistance (IR) is the prevalent finding in PCOS women and it is predominant in women with the classic and severe PCOS phenotype presented with hyperandrogenism and chronic anovulation. One protein that functionally links those two apparently unparalleled phenotypes is SHBG. Insulin has a direct inhibitory effect on SHBG production from the liver, thus PCOS patients often have the lowest levels of SHBG [36] and the high amount of circulating free androgens [37]. The Study of Women's Health Across the Nation (SWAN) shows that low SHBG and high free androgen index are strongly related to metabolic and cardiovascular risk factors: higher insulin, glucose, hemostatic and inflammatory markers and more adverse lipid profile [38]. In this study, we found statistically significant lower levels of SHBG in IGT and DMT2 groups compared to the group with normal glucose tolerance. There are statistically significant differences between normal glucose tolerance and IGT, and between normal glucose tolerance and DMT2 groups of PCOS women. We found, however, that SHBG shows a statistically significant negative correlation with both fasting and 2 hour post-load glycaemia from OGTT. This is consistent with the fact that SHBG has been found to predict the development of type 2 diabetes. Our finding demonstrated the need to perform OGTT in women with PCOS and low levels of SHBG.
Alteration in the lipid profile is a common finding in women with PCOS. A great reduction of high-density lipoproteins (HDL-C) with both increase of triglycerides and total cholesterol levels, has been observed in obese PCOS women and less in lean PCOS women in comparison to normal weight women [39, 40]. Overall, most investigators agree that PCOS women have levels of triglycerides that are twice as high and a $25 \%$ lower concentration of HDL. In our study we found high levels of triglycerides and low levels of HDL-C. Furthermore, we demonstrated a significant negative correlation between FPG and HDL-C, while triglycerides correlated positively with 2 hour post-load glycaemia. Those metabolic patterns are seen in people with DMT2.

\section{CONCLUSIONS}

It seems that the prevalence of IGT and DMT2 among PCOS women in our country is not as high as in Western countries. The prevalence rate of IGT and DMT2 increases with age and BMI. The major predictors for abnormal glucose metabolism in PCOS are age, BMI, testosterone and SHBG. Thus, close monitoring of older, obese women with low SHBG is needed because there is a higher risk of developing IGT and DMT2 in these kinds of patients.

\section{REFERENCES}

1. Dunaif A, Segal KR, Shelley DR, et al. Evidence for distinctive and intrinsic defects in insulin action in polycystic ovary syndrome. Diabetes 1992;41:1257-1266.

2. Nolan CJ, Prentki M. Insulin resistance and insulin hypersecretion in the metabolic syndrome and type 2 diabetes: Time for a conceptual framework shift. Diabetes \& Vascular Disease Research 2019; Vol. 16(2) 118-127.

3. Mc Carthy CR, Marshall JC. Polycystic ovary syndrome. New England Journal of Medicine 2016; 375: 54-64. (https//doi.org/10.1056/NEJMcp 1514916)

4. Bajuk Studen K, Pfeifer M. Cardiometabolic risk in polycystic ovary syndrome. Endocrine Connections 2018; 7(7): 238-251.

5. Bednarska S, Siejka A. The pathogenesis and treatment of polycystic ovary syndrome: What's new? Adv Clin Exp Med. 2017; 26(2):359-367. 
6. Otto-Buczkowska E, Grzyb K, Jainta N. Polycystic ovary syndrome (PCOS) and the accompanying disorders of glucose homeostasis among girls at the time of puberty. Pediatr Endocrinol Diabetes Metab. 2018; 24(1):40-44.

7. Tomlinson J. Polycystic ovary syndrome: Why are women at increased risk of type 2 diabetes? Journal of Diabetes Nursing 2016; 3: 91-97.

8. Azziz R, Carmina E, Chen Z, et al. Polycystic ovary syndrome. Nature Reviews Disease Primer 2016; 2:16057. (https.//doi.org/10 1038/ nrdp.20116.57)

9. Gambineri A, Pelusi C, Manicardi E, et al. Glucose intolerance in a large cohort of mediterranean women with polycystic ovary syndrome: phenotype and associated factors. Diabetes 2004; 53:2353-2358.

10. Achard C, Thiers J. Le virilisme pilaire et son association a l' insuffisance glycolytique (diabetes des femmes a barbe)(In French )Bull Acad Natl Med (Paris) 1921; 86:51-64.

11. Burgan GA, Givens JR, Kitabchi AE. Correlation of hyperandrogenism with hyperinsulinism in poycystic ovarian disease. J Clin Endocrinol Metab 1980; 50:113-116.

12. Ehrmann DA, Barnes RB, Rosenfield RL, et al. Prevalence of impaired glucose tolerance and diabetes in women with polycystic ovary syndrome. Diabetes Care 1999; 22: 141-146.

13. Sirman MS, Pate AK. Epidemiology, diagnosis, and management of polycystic ovary syndrome. Clinical Epidemiology 2014; 6: 1-13.

14. Kakoly NS, Khomami MB, Joham AE, et al. Ethnicity, obesity and the prevalence of impaired glucose tolerance and type 2 diabetes in PCOS: a systematic review and meta-regression. Human Reporoduction Update 2018; 1-13.

15. Solomon C, Frank Hu, Dunaif A, et al. Long or highly irregular menstrual cycles as a marker for risk of type 2 diabetes mellitus. JAMA 2001; 286(19): 3421-3426.

16. Rotterdam ESHRE/ASRM-Sponsored PCOS Consensus Workshop Group Revised 2003 consensus on diagnostic criteria and long-term health risks related to polycystic ovary syndrome (PCOS). Human Reproduction 2004; 19: 41- 47.

17. American Diabetes Association Standards of medical care in diabetes - 2014. Diabetes Care 2014; 37: S14- S80.

18. Legro RS, Kunselman AR, Dodson WC, et al. Prevalence and Predictors of Riskfor Type 2 Diabetes Mellitus and Impaired Glucose Tolerance in Polycystic OvarySyndrome: A Prospective, Controlled Study in 254 Affected Women. Journal of Clinical Endocrinology and Metabolism1999;84:165-169.

19. Weerakiet S, Srisombut C, Bunnag P, et al. Prevalence of type 2 diabetes mellitus and impaired glucose tolerance in Asian women with polycystic ovary syndrome. Int J Gynaecol Obstet 2001;75: 177-184.

20. Gambineri A, Pelusi C, Manicardi E, et al. Glucose Intolerance in a Large Cohort of Mediterranean Women With Polycystic Ovary Syndrome Phenotype and Associated Factors. Diabetes 2004; Vol. 53: 2353-2358.

21. Dabadghao P, Roberts BJ, Wang J, et al. Glucose tolerance abnormalities in Australian women with polycystic ovary syndrome. MJA 2007; 187(6): 328-331.

22. Apridonidze T, Essah P, Iuorno MJ, et al. Prevalence and characteristics of the metabolic syndrome in women with polycystic ovary syndrome. J Clin Endocrinol Metab. 2005; 90(4):1929-1935.

23. Carmina E, Napoli N, Longo RA, et al. Metabolic syndrome in polycystic ovary syndrome (PCOS): lower prevalence in southern Italy than in the USA and the influence of criteria for the diagnosis of PCOS. European Journal of Endocrinology 2006; 154: 141-145.

24. Ehrmann DA, Liljenquist DR, Kasza K, et al.Prevalence and predictors of the metabolic syndrome in women with polycystic ovarysyndrome. Journal of Clinical Endocrinology and Metabolism 2006; 91:48-53.

25. Moran LJ, Misso ML, Wild RA, et al. Impaired glucose tolerance, type 2 diabetes and metabolic syndrome in polycystic ovary syndrome: a systematic reviewand meta-analysis. Human Reproduction Update 2010; 16:347-363.

26. Alberti KG, Zimmet P, Shaw J. International Diabetes Federation: a consensus on type 2 diabetes prevention. Diabet Med 2007; 24: 451-463.

27. Livadas S, Kollias A, Panidis D, et al. Diverse impacts of aging on insulin resistance in lean and obese women with polycystic ovary syndrome evidence from 1345 women with the syndrome. European Journal of Endocrinology 2014;171: 301-309. (https.//doi.org/10. 1210/jc.2012-3908)

28. Ciampelli M, Fulghesu AM, Cucinelli F,et al. Impact of insulin and body mass index on metabolic and endocrine variables in polycystic ovary syndrome. Metabolism 1999; 48: 167-172.

29. Yildiz BO, Knochenhauer ES, Azziz R. Impact of obesity on the risk for polycysticovary syndrome. Journal of Clinical Endocrinology and Metabolism 2008; 93:162-168.

30. Lim SS, Norman RJ, Davies MJ, et al. The effect of obesity on polycystic ovary syndrome: a systematic review and meta-analysis. Obesity Reviews 2013; 14: 95-109.

31. Andersen M and Glintborg D. Diagnosis and follow-up of type 2 diabetes in women with PCOS: a role for OGTT? European Journal of Endocrinology. 2018; 179, D1-D14. 
32. Lazaridou S, Dinas K, Tziomalos K. Prevalence, pathogenesis and management of prediabetes and type 2 diabetes mellitus in patients with polycystic ovary syndrome. HORMONES 2017; 16(4):373-380.

33. Barber TM, Vojtechova P, Franks S. The impact of hyperandrogenism in femaleobesity and cardiometabolic diseases associated with polycystic ovary syndrome. Hormone Molecular Biology and Clinical Investigation 2013;15:91-103.

34. Shorakae S, Teede H, de Courten B, et al. The emerging role of chronic low-grade inflammation in the pathophysiology of polycystic ovary syndrome. Semin Reprod Med 2015; 33:257-269.

35. O Reilly WM, Taylor EA, Crabtree JN, et al. Hyperandrogenemia predicts metabolic phenotype in polycystic ovary syndrome: the utility of serum androstenedione. J Clin Endocrinol Metab 2014; 99(3): 1027-1036.

36. Thaler MA, Seifert-Klauss V, Luppa PB. The biomarker sex hormone-bindingglobulin - from established applications to emerging trends in clinical medicine. Best Practice \& Research:
Clinical Endocrinology \& Metabolism 2015; 29:749-760

37. Haffner SM, Valdez RA, Morales PA, et al. Decreased sex hormone-binding globulin predicts noninsulin-dependent diabetes mellitus in women but not in men. J Clin Endocrinol Metab 1993; 77: 56-60.

38. Sutton-Tyrrell K, Wildman RP, Matthews KA, et al.Sex Hormone-Binding Globulin and the Free Androgen Index Are Related toCardiovascular Risk Factors in Multiethnic Premenopausal and Perimenopausal Women Enrolled in the Study of Women Across the Nation (SWAN). Circulation 2005; 111:1242-1249.

39. Diamanti-Kandarakis E, Papavassiliou AG, Kandarakis S A, et al. Pathophysiology and types of dyslipidemia in PCOS. Trends Endocrinol Metab 2007; 18:280-285.

40. Rizzo M, Berneis K, Carmina E, et al. How should we manage atherogenic dyslipidemia inwomen with polycystic ovary syndrome? Am J Obstet Gynecol 2008; 198:28.e21-25. 


\title{
Резиме
}

\section{ПРЕВАЛЕНЦИЈА И ПРЕДИКТОРИ НА НАРУШЕНА ГЛИКОЗНА ТОЛЕРАНЦИЈА И ДИЈАБЕТЕТ МЕЛИТУС ТИП 2 КАЈ ПАЦИЕНТКИ СО СИНДРОМ НА ПОЛИЦИСТИЧНИ ЈАЈНИЦИ}

\author{
Бранкица Крстевска ${ }^{1}$, Саша Јовановска Мишевска ${ }^{2}$, \\ Валентина Велкоска Накова ${ }^{3}$, Владимир Сеарфимоски ${ }^{4}$ \\ ${ }^{1}$ Центар за внатрешни болести Срце, Скопје, РС Македонија, \\ 2 Универзитетска клиника за ендокринологија, дијабетес и метаболички нарушувања, Скопје, РС \\ Македонија \\ ${ }^{3}$ Клиничка болница, Штип, РС Македонија, \\ ${ }^{4}$ Владимир Сеарфимоски, Македонска академија на науките и уметностисте, Скопје, РС Македонија
}

Цел: Процена на преваленцијата на нарушена гликозна толеранција (IGT) и дијабетес мелитус тип 2 (DMT2), како и предикторите за нарушувања во метаболизмот на гликоза кај жени со синдром на полицистични јајници (PCOS).

Материјал и методи: Пресечна студија со 80 последователни пациенти со ново дијагностициран PCOS беа подложени на стандарден тест со $75 \mathrm{~g}$ оптоварување со орална гликоза (OGTT) и мерење на половите стероидни хормони и липидниот профил.

Резултати: Според резултатите од OGTT, 63 \% имаа нормален тест (NT), 23 \% имаа IGT и 9 \% имаа DMT2. Групата NT беше помлада со понизок БМИ од групата IGT и DMT2 $(25,1 \pm 7,3$, $31,5 \pm 6,5,37,4 \pm 4,0$ години и $29,1 \pm 8,3$ кг $/ \mathrm{M}^{2}, 31,7 \pm 4,6$ кг $/ \mathrm{M}^{2}$ и $34,5 \pm 5,6 \mathrm{\kappa г} / \mathrm{M}^{2}$ соодветно). Нивото на тестостерон беше највисоко во групата со нормален тест $(2,7 \pm 0,8 \mathrm{nmol} / \mathrm{l})$ и најниско во групата DMT2 $(1,9 \pm 0,8 \mathrm{nmol} / \mathrm{L})$, со статистичко значење. Нивото на секс-хормон врзувачки глобулин (SHBG) беше ниско во сите три групи, со статистички значајни разлики меѓу NG и IGT и групите NT и DMT2. Мултиваријатниот линеарен регресивен модел ги идентификуваше возраста, БМИ, SHBG и тестостеронот како главни независни предиктори за абнормален метаболизам на гликоза.

Заклучок: Се чини дека преваленцијата на IGT и DMT2 кај жените co PCOS во нашата земја не е толку голема како во западните земји. Возраста, БМИ и SHBG го зголемуваат ризикот за развој на IGT и DMT2. Потребно е внимателно следење на постарите дебели жени со низок SHBG, поради поголем ризик за развој на IGT и DMT2 кај таквите пациентки.

Клучни зборови: синдром на полицистични јајници, орален глукозен толерантен тест, нарушена гликозна толеранција, дијабетес мелитус тип 2, тестостерон 